\title{
Gracilis muscle transposition for treatment of recurrent anovaginal, rectovaginal, rectourethral, and pouch-vaginal fistulas in patients with inflammatory bowel disease
}

\author{
S. Korsun ${ }^{1}$ - G. Liebig-Hoerl ${ }^{1}$ - A. Fuerst ${ }^{1}$
}

Received: 17 November 2018 / Accepted: 17 December 2018 / Published online: 2 January 2019

(c) The Author(s) 2019, corrected publication 2019

\begin{abstract}
Background The aim of this study was to evaluate the effectiveness of gracilis muscle transposition (GMT) to treat recurrent anovaginal, rectovaginal, rectourethral, and pouch-vaginal fistulas in patients with inflammatory bowel disease (IBD). Methods A retrospective study was conducted in patients with IBD who had GMT performed by a single surgeon between 2000 and 2018. Follow-up data regarding healing rate, complications, additional procedures, and stoma closure rate was collected.

Results A total of 30 women and 2 men had GMT. In all patients fistula was associated with Crohn's disease. In 1 female patient, contralateral gracilis transposition was required after a failed attempt at repair. The primary healing rate was $47 \%$ $(15 / 32)$ and the definitive healing rate (healed by the time of data collection and after secondary procedures) was $71 \%$ (23/32). Additional surgical procedures due to fistula persistence or recurrence were performed on 17 patients (53\%).At least 7 patients (21\%) suffered complications including one wound infection with ischemia of the gracilis muscle. Stoma closure was successful in 18 of 31 cases of patients with stoma (58\% of the patients).

Conclusions GMT for the treatment of recurrent and complex anorectal fistulas in patients with IBD patient is eventually successful in almost $2 / 3$ of patients.
\end{abstract}

Keywords Crohn disease $\cdot$ Fecal incontinence $\cdot$ Surgical flaps $\cdot$ Surgical stomas

\section{Introduction}

Treatment of recurrent and complex anorectal fistulas is challenging. Surgical therapy for fistulas in patients with inflammatory bowel disease (IBD) is associated with high recurrence rates. Fistulas in patients with IBD result from chronic relapsing inflammation with subsequent intestinal fibrosis and stricture formation, and could be triggered by the epithelial-mesenchymal transition [1-3]. The etiology of the fistula reflects the existing comorbidities, which should also be addressed intraoperatively (e.g., perineal defects and scar tissue with compromised local vascularization as a result of previous colorectal procedures). Depending on the location of the fistula, different approaches can be used, including transabdominal, transperitoneal, or local techniques. A number of local surgical methods exist, such as excision, advancement flaps, and fibrin glue or biomesh application. Autologous muscle flaps-such as the Martius, sartorius, and gracilis flaps-are muscles flaps-such as the Martius, sartorius, and gracilis flaps-are further methods for fistula closure. However, no consensus regarding the preferred method of choice has been reached. Combining different procedures after an insufficient fistula closure may be useful to improve the efficacy of a single method. Larger recent studies [4-10] on GMT, including those of Ulrich et al. [6] and Wexner et al. [9], have demonstrated some excellent results.

A. Fuerst

afuerst@caritasstjosef.de

1 Department of Surgery, Caritas Clinic St. Josef, Landshuter Str. 65, 93053 Regensburg, Germany 


\section{Materials and methods}

\section{Study design and patients}

A two-center retrospective study was performed from January 2000 to May 2018 in patients diagnosed with IBD. All patients underwent GMT at the surgery departments of the University Hospital Regensburg and the St. Josef Hospital Regensburg, Germany, between January 2000 and May 2018 to treat anovaginal, rectovaginal (RVF), rectourethral (RUF), and pouch-vaginal fistulas. All gracilis transpositions were performed by a single surgeon (AF). IBD patients who underwent GMT strictly due to fecal incontinence and not for fistula treatment were excluded. Follow-up procedures in cases of fistula recurrence were performed by other surgeons. Prior to GMT, all patients had undergone at least one failed attempt at fistula repair using various other procedures such as fistulotomy, fistulectomy, mucosal advancement flap, fistula plug, fibrin glue application.

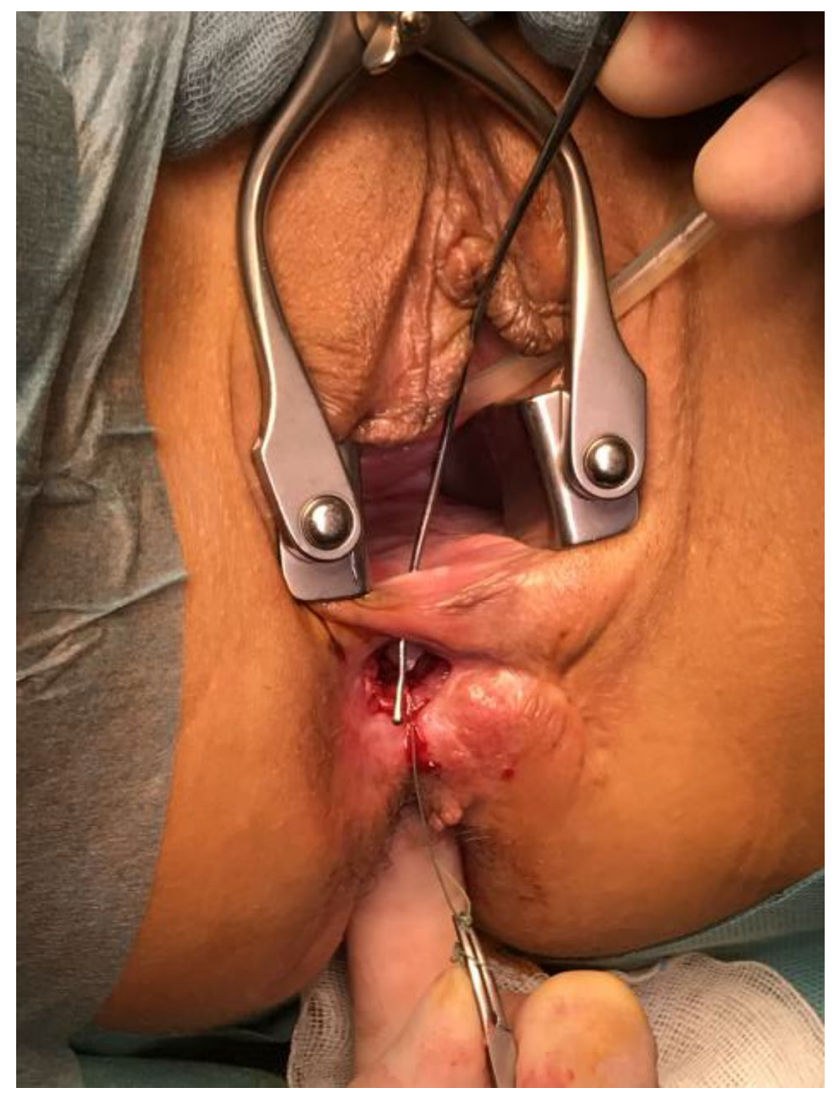

Fig. 1 Complex rectovaginal and perineal fistula combined with a perineal defect

\section{Surgical technique}

GMT was performed according to a standardized procedure [11]. We combined the GMT in all cases but one with a fecal diversion performing a loop ileostomy if no stoma existed. We prefer performing a GMT when a stoma is already established to reduce the local infection beforehand. Antibiotic prophylaxe with cefuroxime und metronidazole was given perioperatively. The fistula tract was identified by probing (Fig. 1) and excised completely. The defect on the rectal side was minimized with interrupted sutures. The gracilis muscle was identified and an incision measuring approximately 10-12 cm was made on the medial side of the thigh (Fig. 2). The distal muscle tendon was then identified by palpation near the pes anserinus and divided after a small incision medial to the knee joint. The muscle was mobilized and the small collateral blood vessels in the distal part of the muscle were ligated using ties for the bigger blood vessels and coagulation for the smaller ones. During mobilization, great care was taken to find a tension-free position of the neurovascular bundle on the lateral proximal side of the gracilis muscle. A subcutaneous tunnel between the ipsilateral proximal medial side of the thigh and the perineal region was created by blunt preparation. The muscle then was pulled through the tunnel and placed exactly underneath the suture line closing the rectal side of the fistula (Fig. 3), covering the rectum, placing well-vascularized tissue in the defect area (Fig. 4). Rotation of the muscle around its axis was carefully avoided. The distal tendon of the muscle was then fixed with Prolene sutures (Ethicon, Bridgewater, NJ and Cincinnati, OH, USA) to the contralateral pubic or ischial periosteum after transposition through an additional subcutaneous tunnel and a small incision on this side. Finally, the gracilis muscle was covered by a soft tissue flap (Fig. 5). If the medical history of the patient

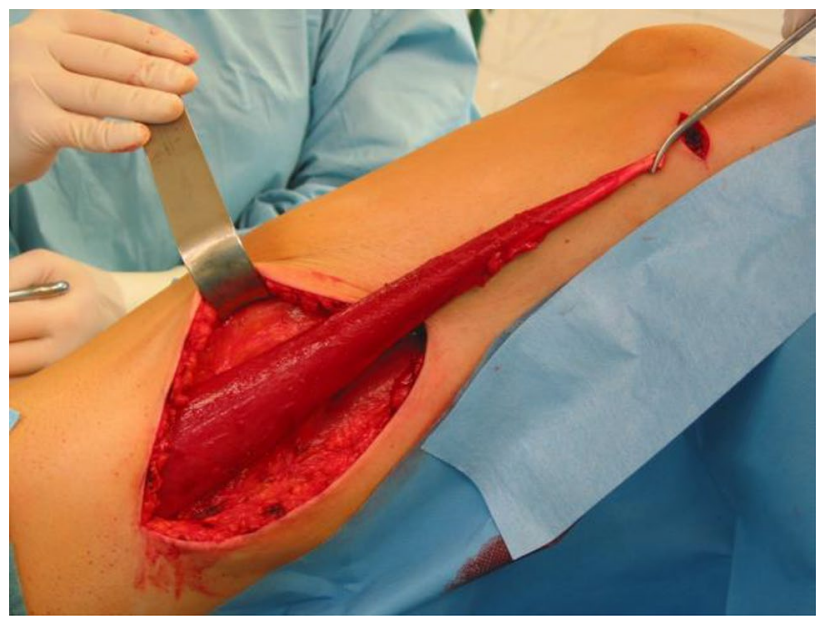

Fig. 2 Mobilization of the gracilis muscle 


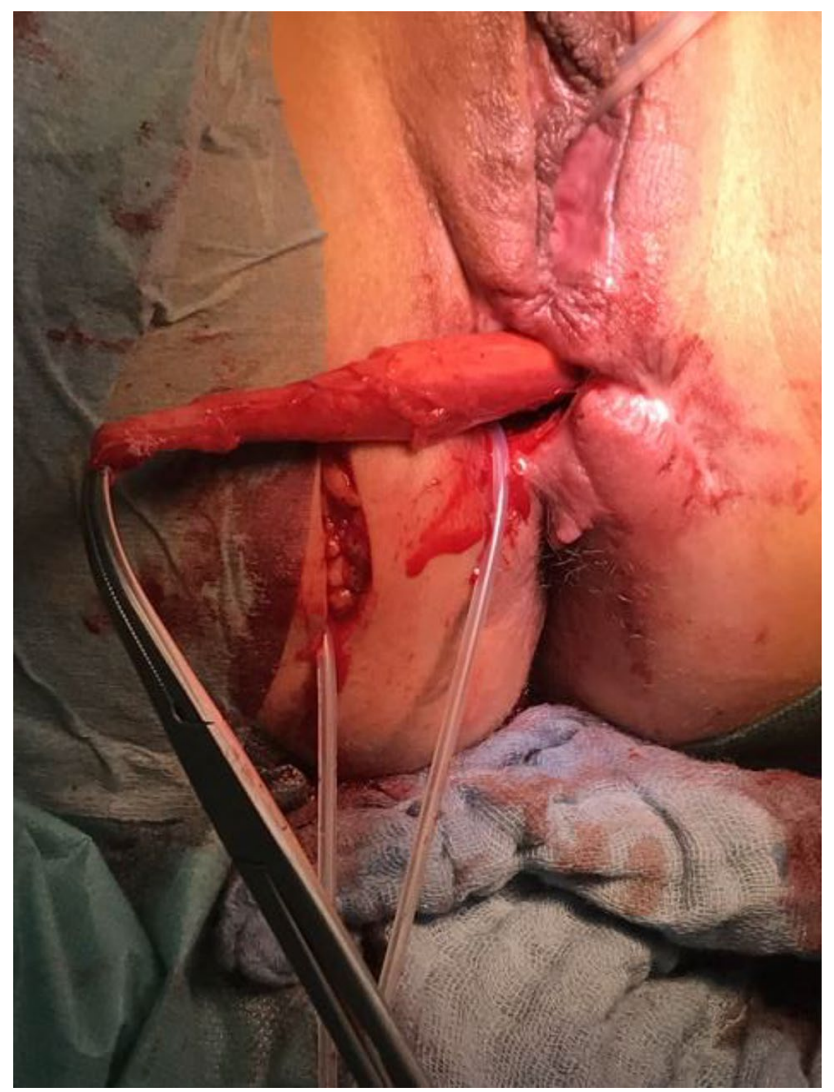

Fig. 3 Transposition of the gracilis muscle

indicated fecal incontinence, the distal muscle tendon was transposed further to encircle the anal canal, and fixed at the ipsilateral pubic or ischial periosteum, thus creating a loop (gamma-loop; Fig. 6). This procedure potentially increases anal continence by contributing additional muscle tension. A secondary dynamization of the gracilis muscle remains an additional option for optimization of anal sphincter function. If no fecal diversion existed preoperatively, a protective stoma was added simultaneously. Only 1 patient opted against a protective stoma.

\section{Outcome assessment}

The primary outcome measure was complete closure of the fistula by the first follow-up (approximately 3 months postoperatively) without additional follow-up operations. In patients with anovaginal, rectovaginal, and pouch-vaginal fistulas, the initial follow-up was performed 3 months postoperatively. A sensitive sign of the presence of a residual fistula is a feeling of air-trapping and vaginal discharge. All patients had clinical examination, including anoscopy, air insufflation, and fistula probing (in selected cases under general anesthesia). In case of uncertainty regarding a residual fistula, a watersoluble contrast enema, anorectal endosonography, or pelvic

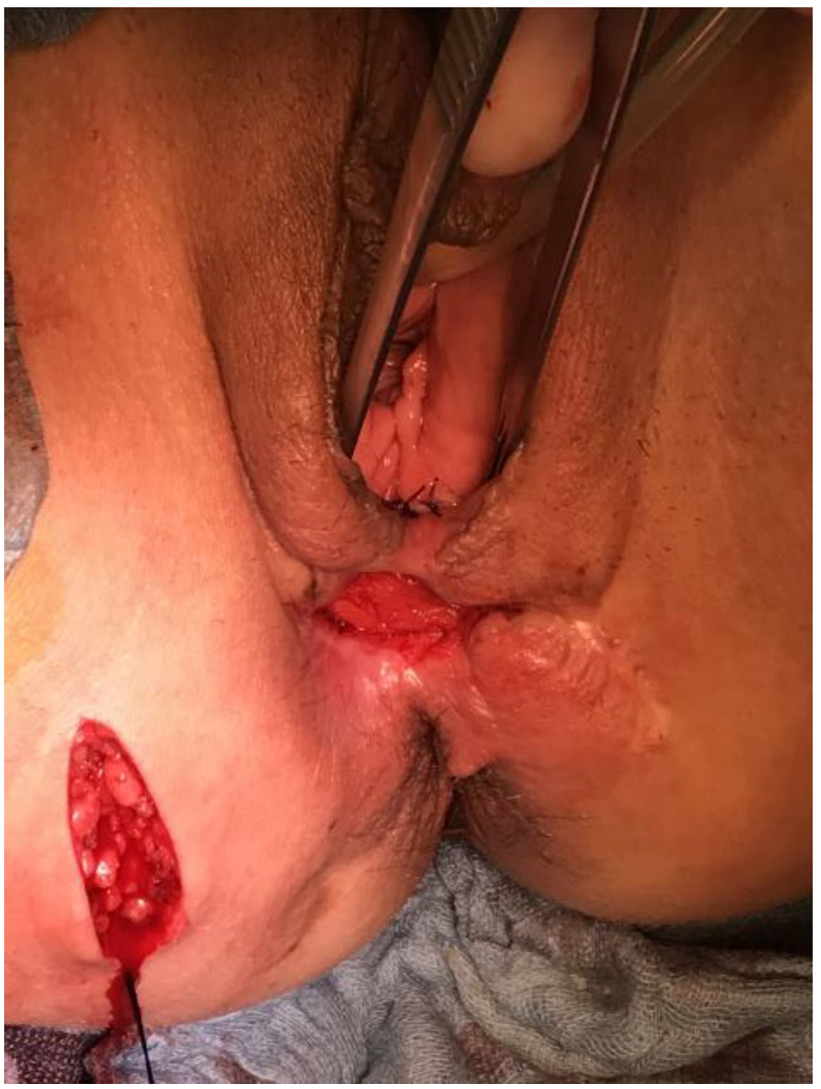

Fig. 4 Fixation of the gracilis muscle on the contralateral pubic periost (tunneling technique)

magnetic resonance imaging was performed. Stoma reversal was performed upon definitive closure of a fistula tract.

Secondary outcomes included fistula closure after followup procedures in cases of fistula persistence and stoma closure rate. Fistula-free time in cases of late recurrences was also documented.

\section{Data analysis}

Information regarding patients' demographic characteristics, number of previous operations, types of fistula, fistula closure, complications, follow-up procedures, and stoma closure was collected retrospectively from medical records. Data were gathered in a Microsoft Excel Sheet Version 2010 (Microsoft Corporation, Redmond, WA, USA). Data are presented using summary statistics in the form of means and median values for quantitative data and percentages for qualitative data. 


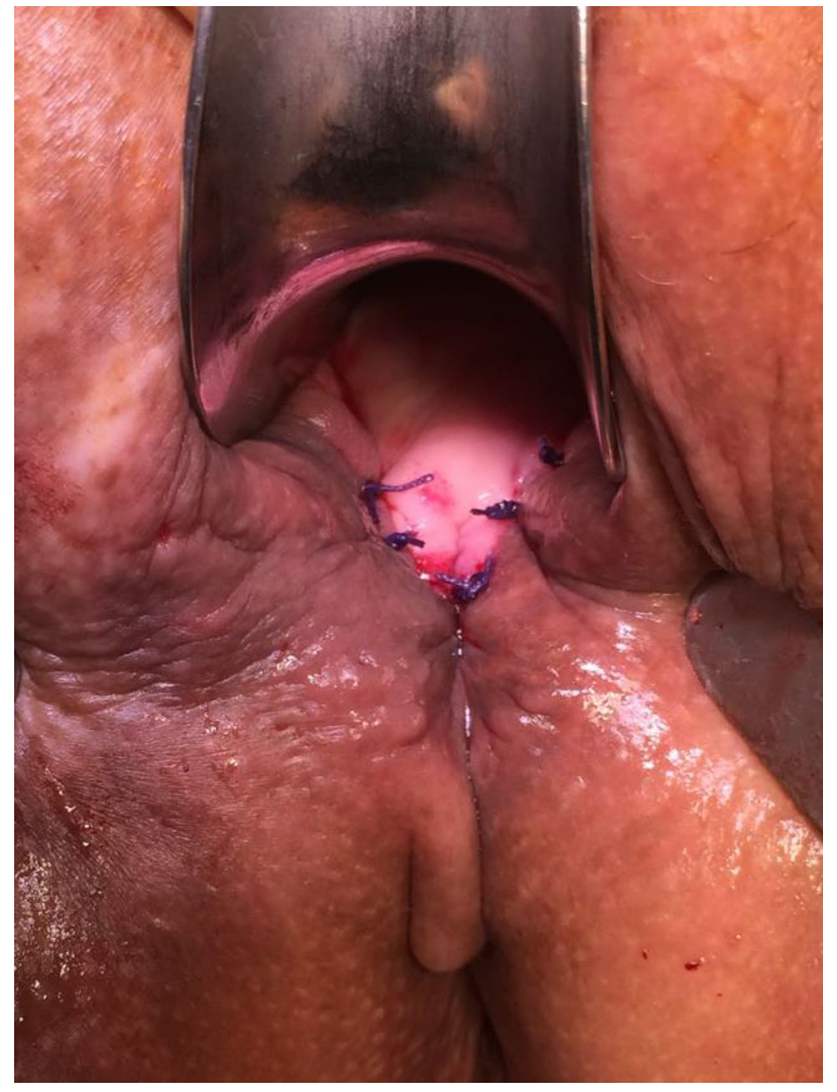

Fig. 5 Vaginal flap to cover the gracilis muscle

\section{Ethical considerations}

Due to the retrospective nature of the study, formal consent was not required. The study was approved by the local ethics committee of the authors' study center.

\section{Results}

A total of 32 patients ( 2 male, 30 female; mean age 39 years, range 24-55 years) with IBD underwent gracilis transposition or re-transposition for a recurrent fistula at the authors' institutions between January 2000 and March 2018 and attended at least the first follow-up visit at 3 months. Two patients with less than 3 months of follow-up were also included (one because of graft ischemia and the other because of a persistent fistula) to minimize selection bias and present a more realistic recurrence and complication rate. All patients had undergone diverse previous surgical procedures for fistula closure (mean 2 procedures, range 1-25 procedures) before the gracilis transposition. Mean follow-up time after GMT was 47 months (range 1-144 months). After GMT, some patients suffered a recurrence or had a smaller

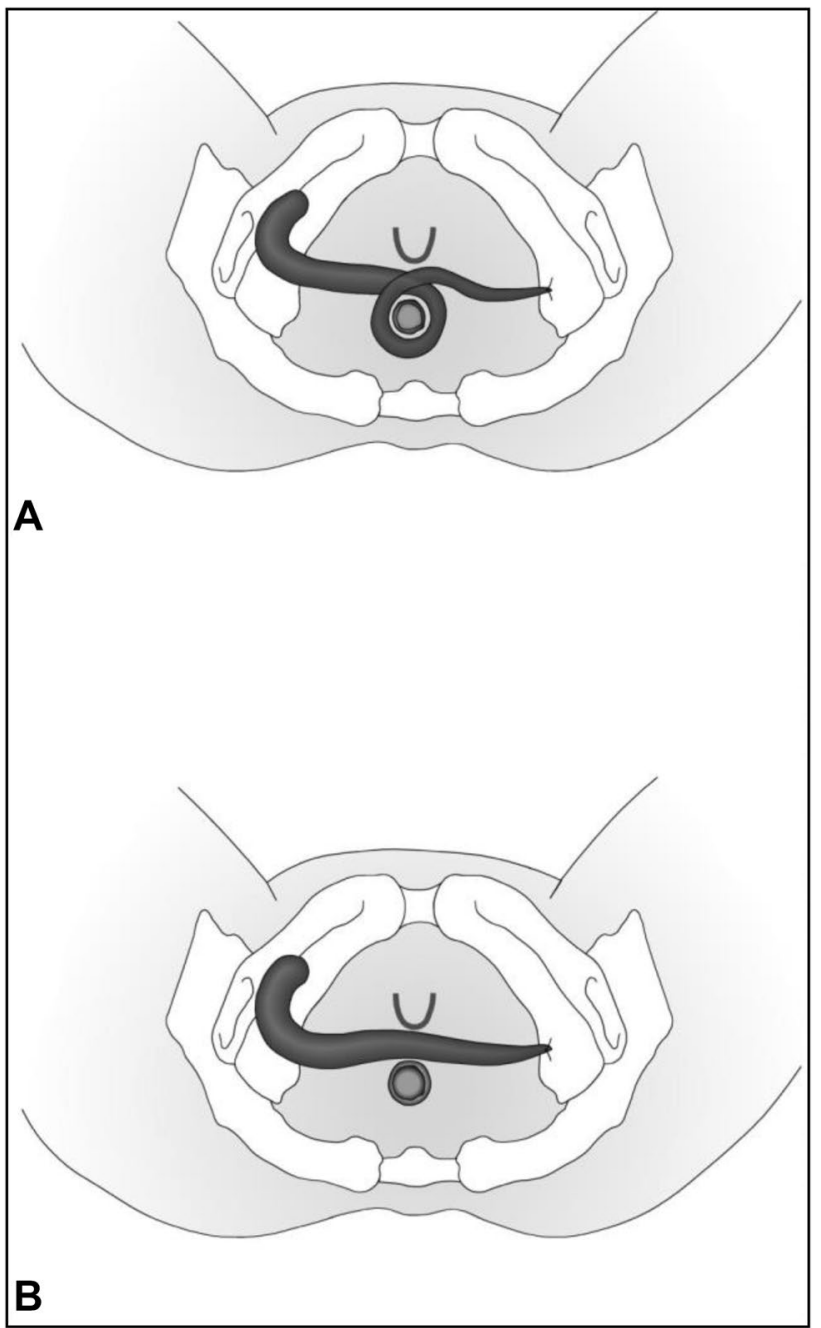

Fig. 6 Types of gracilis muscle transposition (GMT) [10]. a Circular GMT, b transverse GMT

residual fistula, prompting different follow-up procedures to achieve definitive closure (Tables 1, 2 and 3).

Of the 32 patients with IBD, 1 developed a wound infection with necrosis of the gracilis flap and 7 had a residual fistula at the first postoperative follow-up and required additional procedures. During the subsequent follow-up period, 9 further patients had a recurrent or new fistula and one patient had an abscess without a verification of a fistula (median time after GMT among these 9 patients before recurrence: 17 months; range 5-62 months). In 7 of those cases a recurrence took place after stoma closure (median time after stoma closure until recurrence 17 months, range 2-59). It was difficult to distinguish whether the patient had a recurrence or a new spontaneous fistula due to Crohn's disease (CD). In 1 patient, a recurrence was documented directly after a CD relapse. The primary fistula closing rate where the fistula stayed closed during the follow-up and no further procedures were needed was $47 \%$ (15/32). 
Table 1 Additional procedures after GMT for patients with recurrence

\begin{tabular}{|c|c|c|c|}
\hline Patient & Date of GMT & Follow-up procedures & Last follow-up \\
\hline I & $09 / 2002$ & $\begin{array}{l}\text { 12/2002 stoma closure } \\
12 / 2005 \text { recurrence } \\
03 / 2006 \text { abscess excision and fistulectomy } \\
05 / 2006 \text { fistulectomy and double barrel ileostomy }\end{array}$ & 09/2013 fistula not closed \\
\hline II & $04 / 2005$ & $\begin{array}{l}\text { 07/2005 stoma closure } \\
02 / 2010 \text { recurrence/ new fistula } \\
02 / 2010 \text { fistulectomy } \\
\text { 04/2010 fistulectomy, rectal muscle flap and } \\
\text { fistula plug } \\
\text { 08/2010 vaginal advancement flap } \\
\text { 09/2010 loop sigmoidostomy } \\
11 / 2010 \text { fistulectomy and vaginal flap } \\
\text { 03/2011 stoma closure }\end{array}$ & 03/2011 fistula closed \\
\hline III & $04 / 2013$ & $\begin{array}{l}07 / 2013 \text { stoma closure } \\
10 / 2013 \text { recurrence } \\
11 / 2013 \text { biomesh } \\
12 / 2013 \text { seton } \\
\text { 06/2015 vaginal flap } \\
03 / 2018 \text { seton }\end{array}$ & 03/2018 fistula not closed \\
\hline IV & $06 / 2009$ & $\begin{array}{l}\text { 09/2009 stoma closure } \\
08 / 2014 \text { recurrence after crohn relapse } \\
10 / 2014 \text { rectal flap } \\
11 / 2014 \text { fistulectomy and rectal flap } \\
02 / 2015 \text { rectal flap and double barrel colostomy } \\
\text { 03/2015 rectal and vaginal flap } \\
05 / 2015 \text { rectal flap } \\
\text { 09/2017 fistulectomy and rectal flap } \\
02 / 2018 \text { martius flap }\end{array}$ & 03/2018 fistula not closed \\
\hline $\mathrm{V}$ & $12 / 2015$ & $\begin{array}{l}\text { 02/2016 stoma closure } \\
\text { 04/2017 abscess excision } \\
07 / 2017 \text { fistulectomy }\end{array}$ & 08/2017 fistula closed \\
\hline VI & $02 / 2016$ & $\begin{array}{l}09 / 2016 \text { stoma closure } \\
11 / 2016 \text { fistulectomy }\end{array}$ & 12/2017 fistula closed \\
\hline VII & $10 / 2005$ & $\begin{array}{l}\text { 07/2006 stoma closure } \\
\text { 03/2007 recurrence } \\
\text { 03/2007 abscess excision } \\
12 / 2007 \text { seton and double barrel ileostomy }\end{array}$ & 12/2007 house ban, fistula not closed \\
\hline VIII & $05 / 2016$ & $\begin{array}{l}\text { 12/2016 recurrence } \\
12 / 2016 \text { abscess excision } \\
\text { 02/2017 fistulectomy and rectal flap } \\
\text { 03/2017 abscess excision } \\
\text { 03/2018 stoma closure }\end{array}$ & 03/2018 fistula closed \\
\hline IX & $05 / 2006$ & $\begin{array}{l}10 / 2006 \text { recurrence } \\
11 / 2006 \text { fistulectomy and rectal advancement flap }\end{array}$ & $11 / 2009$ fistula closed \\
\hline
\end{tabular}

In total, an additional 43 operations were required for the 17 patients with recurrences and persistence of a fistula after GMT to achieve a definitive fistula closure rate after recurrences of $71 \%$ (23/32) among all 32 patients (Table 1). Of these operations, 17 were performed to close a recurrent or persistent fistula in 8 patients ( 2.1 follow-up procedures per patient per closed fistula after recurrence or persistence). Despite performing a total of 26 other follow-up procedures on 9 other patients, those 9 other patients had a persistent fistula and in one another case there is a suspicion of a recurrence due to an abscess without a clinical proof of a fistula.
At the time of GMT, 15 patients were not taking any specific CD medication (Table 4). In six of those cases the fistula healed without follow procedures. Only in 4 of those 15 patients (healing rate $73 \%$ ) without specific CD medication at the time of GMT a fistula remained after follow procedures. In 5 of the 17 cases (healing rate $71 \%$ ) where patients took a specific CD medication a residual fistula remained after follow procedures. However, the $\mathrm{p}$ value for comparing the healing rate with or without specific CD medication is 0.589 and thus not of statistical significance. 
Table 2 Additional procedures after GMT for patients with fistula persistence

\begin{tabular}{|c|c|c|c|}
\hline Patient & Date of GMT & Follow-up procedures & Last follow-up \\
\hline I & $03 / 2016$ & $\begin{array}{l}\text { Persistence } \\
05 / 2016 \text { fistulectomy } \\
04 / 2017 \text { fistulectomy and rectal flap } \\
03 / 2018 \text { fistulectomy and rectal flap }\end{array}$ & 03/2018 fistula not closed \\
\hline II & $05 / 2014$ & $\begin{array}{l}\text { Persistence } \\
04 / 2015 \text { rectal flap } \\
11 / 2016 \text { stoma closure }\end{array}$ & $11 / 2016$ fistula closed \\
\hline III & $03 / 2015$ & $\begin{array}{l}\text { Persistence } \\
06 / 2015 \text { rectal flap } \\
10 / 2015 \text { stoma closure }\end{array}$ & 10/2015 fistula closed \\
\hline IV & $01 / 2000$ & $\begin{array}{l}\text { Persistence } \\
\text { 03/2000 vaginal flap } \\
\text { 09/2007 proctocolectomy and converting loop ileostomy in double barrel } \\
\text { ileostomy (not because of fistula) } \\
\text { 05/2010 abscess excision }\end{array}$ & 01/2012 fistula closed \\
\hline V & $07 / 2014$ & $\begin{array}{l}\text { Persistence } \\
09 / 2014 \text { vaginal flap } \\
02 / 2015 \text { rectal flap } \\
05 / 2015 \text { vaginal flap } \\
12 / 2015 \text { vaginal flap } \\
03 / 2017 \text { seton }\end{array}$ & $11 / 2017$ fistula not closed \\
\hline VI & $02 / 2016$ & $\begin{array}{l}\text { Persistence } \\
04 / 2016 \text { vaginal flap }\end{array}$ & 04/2016 fistula not closed \\
\hline VII & $05 / 2012$ & $\begin{array}{l}\text { Persistence } \\
10 / 2012 \text { fistulectomy, vaginal and rectal flap and fistula plug } \\
02 / 2013 \text { fistulectomy and vaginal flap }\end{array}$ & 04/2013 fistula not closed \\
\hline VIII & $07 / 2015$ & $08 / 2015$ wound infection with necrosis and excision of the gracilis flap & 10/2015 fistula not closed \\
\hline
\end{tabular}

Table 3 Fistula closure rate after follow-up procedures depending on gender

\begin{tabular}{ll}
\hline Female IBD patients & Male IBD patients \\
\hline$n=21 / 30$ & $n=2 / 2$ \\
$70 \%$ & $100 \%$ \\
\hline
\end{tabular}

$I B D$ inflammatory bowel disease

GMT was performed without fecal diversion in 1 patient and the fistula healed anyway. In 19 patients, the stoma could be reversed after fistula closure and in 2 patients, stoma reversal is intended after fistula healing. A late recurrence after stoma reversal was suffered by 7 patients, 4 of whom received a new stoma with follow-up surgical procedures thereafter. As a result, in 3 of the 7 latter cases, fistula closure was achieved. In summary, a stoma reversal after follow-up procedures due to fistula persistence or recurrence was achieved in 18 of $31(58 \%)$ of the stoma patients and in two other cases where a fistula closure has been achieved a stoma closure is being planned.

Mean age was 42 years (median 43 years, range 24-54 years, 95\% CI 33-51 years) in the patients with complete remission after GMT and 40 years (median 41 years, range
27-55 years, 95\% CI 33-49 years) in the patients who suffered a recurrence $(p=\mathrm{ns})$.

The mean number of operations before GMT was 4.3 (median3, range 1-20) and 4.4 (median2, range 1-25) in the groups who did not and did suffer a recurrence, respectively ( $p=\mathrm{ns})$.

There was no difference in fistula closure rates between patients who received a gamma-loop of gracilis muscle to the ipsilateral pubic ramus $(7 / 10,70 \%)$ and those who underwent GMT on the contralateral pubic ramus $(15 / 22$, $68,1 \%)(p=\mathrm{ns})$.

Data were collected on fistula closure and the closure rate by fistula etiology was calculated (Table 5).

\section{Complications}

Aside from 1 case of wound infection with ischemia of the gracilis muscle, 1 case of postoperative hemorrhage in the thigh 2 cases of suture granuloma and complaints about scar tissue and some numbness on the operated thigh, no other major complications following harvesting and inserting of the gracilis muscle were documented.

When a new fecal diversion was performed during the same session, some patients needed postoperative intravenous fluid 
Table 4 CD medication at the time of GMT

\begin{tabular}{|c|c|c|c|c|c|c|c|}
\hline Patient no. & Gender & CD onset (year) & GMT (year) & $\begin{array}{l}\text { Fistula } \\
\text { closed }\end{array}$ & $\begin{array}{l}\text { Perioperative IBD medi- } \\
\text { cation }\end{array}$ & $\begin{array}{l}\text { IBD Medication before } \\
\text { GMT }\end{array}$ & IBD medication after GMT \\
\hline 1 & $\mathrm{f}$ & 1984 & 2000 & $\mathrm{y}$ & $\begin{array}{l}\text { Short chain fatty acid } \\
\text { enema }\end{array}$ & $\begin{array}{l}1997 \text { steroids; } 1998 \\
\text { azathioprine }\end{array}$ & $\begin{array}{l}2002 \text { and } 2005 \text { mesalazine } \\
\text { foam, steroids }\end{array}$ \\
\hline 2 & f & 1985 & 2001 & $\mathrm{y}$ & $\begin{array}{l}\text { Azathioprine, steroids, } \\
\text { colifoam }\end{array}$ & Unknown & Unknown \\
\hline 3 & $\mathrm{f}$ & 1989 & 2004 & $\mathrm{y}$ & None & Unknown & Unknown \\
\hline 4 & $\mathrm{f}$ & 1988 & 2004 & $\mathrm{y}$ & Azathioprine and steroids & $\begin{array}{l}2001 \text { azathioprine, } \\
\text { steroids }\end{array}$ & 2007 azathioprine, steroids \\
\hline 5 & f & 1984 & 2010 & $\mathrm{y}$ & None & Unknown & Unknown \\
\hline 6 & $\mathrm{f}$ & 2003 & 2010 & $\mathrm{y}$ & Mercaptopurine & $\begin{array}{l}\text { 02/2010 adalimumab, } \\
\text { mercaptopurine }\end{array}$ & Unknown \\
\hline 7 & $\mathrm{~m}$ & 2000 & 2005 & $\mathrm{y}$ & None & Unknown & 09/2005 azathioprine \\
\hline 8 & $\mathrm{~m}$ & 1989 & 2012 & $\mathrm{y}$ & Azathioprine & 11/2011 azathioprine & $12 / 2012$ azathioprine \\
\hline 9 & f & 2002 & 2014 & $\mathrm{y}$ & adalimumab (pause) & $12 / 2013$ adalimumab & 03/2015 adalimumab \\
\hline 10 & $\mathrm{f}$ & 1994 & 2010 & $\mathrm{y}$ & $\begin{array}{l}\text { Adalimumab, azathio- } \\
\text { prine, steroids }\end{array}$ & Unknown & Unknown \\
\hline 11 & f & 2006 & $2005 / 2006$ & $\mathrm{y}$ & None & Unknown & Unknown \\
\hline 12 & $\mathrm{f}$ & 1988 & 2002 & $\mathrm{n}$ & $\begin{array}{l}\text { Azathioprine, steroids, } \\
\text { mesalazine foam }\end{array}$ & Unknown & $\begin{array}{l}\text { 2005, 2006, } 2013 \text { azathio- } \\
\text { prine }\end{array}$ \\
\hline 13 & f & 2001 & 2005 & $\mathrm{y}$ & None & Unknown & $\begin{array}{l}2010 \text { none; } 2011 \text { none; } \\
2014 \text { steroids }\end{array}$ \\
\hline 14 & f & 1984 & 2006 & $\mathrm{y}$ & None & Unknown & 2016 azathioprine \\
\hline 15 & $\mathrm{f}$ & 1997 & 2005 & $\mathrm{n}$ & None & Infliximab & 2007 azathioprine, steroids \\
\hline 16 & $f$ & 2012 & 2012 & $\mathrm{n}$ & None & None & None \\
\hline 17 & $\mathrm{f}$ & 1995 & 2012 & $\mathrm{n}$ & Steroids & Unknown & Unknown \\
\hline 18 & $\mathrm{f}$ & 2005 & 2013 & $\mathrm{n}$ & None & Unknown & 07/2013 sulfasalazine supp \\
\hline 19 & $\mathrm{f}$ & 2007 & 2009 & $\mathrm{n}$ & Methotrexate (MTX) & Unknown & $\begin{array}{l}\text { 09/2009 MTX; 2014- } \\
\text { 2015 MTX, steroids; } \\
\text { 10/2015-2016 steroids, } \\
\text { golimumab; 09/2016 } \\
\text { adalimumab }\end{array}$ \\
\hline 20 & f & 1999 & 2014 & $\mathrm{y}$ & Sulfasalazine & 02/2012 sulfasalazine & $\begin{array}{l}2014 \text { sulfasalazine; } 2015 \\
\text { sulfasalazine, steroids, } \\
\text { azathioprine }\end{array}$ \\
\hline 21 & $f$ & 2002 & 2014 & $\mathrm{y}$ & None & Unknown & $11 / 2016$ none \\
\hline 22 & f & 2006 & 2015 & $\mathrm{y}$ & None & $\begin{array}{l}\text { 10/2014 steroids, adali- } \\
\text { mumab }\end{array}$ & $10 / 2015$ vedolizumab \\
\hline 23 & $f$ & 1988 & 2000 & $\mathrm{y}$ & $\begin{array}{l}\text { Azathioprine, steroids, } \\
\text { sulfasalazine }\end{array}$ & Unknown & $\begin{array}{l}\text { 10/2002 steroids, azathio- } \\
\text { prine; } 2006 \text { azathioprine }\end{array}$ \\
\hline 24 & $\mathrm{f}$ & 2010 & 2015 & $\mathrm{y}$ & Azathioprine & Azathioprine, mesalazine & 10/2015 azathioprine \\
\hline 25 & $\mathrm{f}$ & 2005 & 2016 & $\mathrm{y}$ & None & Unknown & None \\
\hline 26 & $\mathrm{f}$ & 1998 & 2015 & $\mathrm{y}$ & None & Unknown & None \\
\hline 27 & $\mathrm{f}$ & 1995 & 2015 & $\mathrm{y}$ & Sulfasalazine & Unknown & 07/2017 steroid foam \\
\hline 28 & $\mathrm{f}$ & 2005 & 2016 & $\mathrm{y}$ & None & Infliximab & Unknown \\
\hline 29 & $f$ & 2007 & 2016 & $\mathrm{y}$ & Vedolizumab (pause) & Vedolizumab & $\begin{array}{l}\text { 02/2017 vedolizumab; } \\
\text { 03/2018 ustekinumab }\end{array}$ \\
\hline 30 & $f$ & 1992 & 2015 & $\mathrm{n}$ & None & Unknown & None \\
\hline 31 & $\mathrm{f}$ & 1998 & 2016 & $\mathrm{n}$ & Mercaptopurine & Mercaptopurine & 2016 mercaptopurine \\
\hline 32 & $f$ & 2008 & 2016 & $\mathrm{n}$ & Azathioprine, steroids & Azathioprine, steroids & $\begin{array}{l}\text { 05/2016 azathioprine, } \\
\text { steroids; 04/2017 aza- } \\
\text { thioprine }\end{array}$ \\
\hline
\end{tabular}

$f$ female, $m$ male, $y$ yes, $n$ no, GMT gracilis muscle transposition, $C D$ Crohn's disease, IBD inflammatory bowel disease 
Table 5 Fistula closure rate among patients with IBD

\begin{tabular}{lll}
\hline Fistula types & Fistula closure rate & Stoma closure rate \\
\hline Rectovaginal fistula $n=21$ & $\begin{array}{c}71 \% \text { (incl. one patient with an abscess after GMT } \\
\text { (ithout fistula proof) }\end{array}$ & $\begin{array}{c}55 \% \text { (1 patient operated without stoma and 1 } \\
\text { patient opting against stoma closure after fistula } \\
\text { closure) }\end{array}$ \\
Anovaginal fistula $n=2$ & $50 \%$ & $50 \%$ \\
Anal fistula $n=4$ & $100 \%$ & $100 \%$ \\
Pouch fistula $n=3$ & $67 \%$ & $67 \%$ \\
Complex fistula $n=1$ & $0 \%$ & $0 \%$ \\
Rectourethral fistula $n=1$ & $100 \%$ & $0 \%$ \\
Total $n=32$ & $71 \%$ & $58 \%$ \\
\hline
\end{tabular}

$I B D$ inflammatory bowel disease

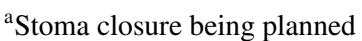

Table 6 Complications

\begin{tabular}{ll}
\hline Complications & $\begin{array}{l}\text { Num- } \\
\text { ber of } \\
\text { patients }\end{array}$ \\
\hline Postoperative hemorrhage & 1 \\
Thigh swelling & 1 \\
Lymphoedema & 1 \\
Suture granuloma & 2 \\
Knee pain & 1 \\
Thigh hypoesthesia & 2 \\
Necrosis of the gracilis muscle & 1 \\
\hline
\end{tabular}

and laxative agents due to ongoing paralytic ileus, but no surgical interventions were needed (Table 6).

\section{Discussion}

Muscle grafts, particularly gracilis muscle grafts, have been in use since the 1930s. It should be noted that the gracilis muscle does not close the existing fistulas per se, but is used to reduce dead space in the perineum and improve vascularization and healing in areas with compromised blood supply due to soft tissue and muscle loss as a result of previous operations. GMT can be combined with other surgical interventions and, thus, improve the rate of fistula closure.

Alternative approaches include transperineal, endorectal, endovaginal, and transabdominal procedures. Fistula closure can be achieved directly using sutures or glue, with a mucosal flap or biomaterials, via partial bowel resection with anastomosis, or through muscle flap transposition. Fecal diversion can be performed as a stand-alone treatment or used perioperatively as a supplementary measure in some surgical procedures.
Biomaterials represent a relatively new method of treating fistulas. Benefits include less intraoperative trauma and a decreased impact on fecal continence, while treating trans-sphincteric fistulas with moderate-good outcomes [12-17]. Chan et al. [18] showed good results using a fistula plug in simple fistulas, but also a decrease in efficacy after multiple procedures. Other studies showed a high rate of postoperative sepsis after implantation of fistula plugs alone $[19,20]$. In combination with a draining seton or an advancement flap, the success rate increases. Long-term studies of this method are necessary to judge its efficacy.

Panés et al. [21-23] describe a promising new therapeutic approach to close treatment-refractory complex perianal fistulas in CD using a single intralesional injection of allogeneic expanded adipose-derived stem cells. This method achieved a $50 \%$ remission rate (53 of 107 patients) in an intention-to-treat population. The most common treatmentrelated adverse events were anal abscess and proctalgia.

The fistula closing rates by sex are shown in (Table 3); however, the significantly smaller number of patients in the male group makes comparisons difficult. All in all, we achieved a definitive fistula closing rate of $71 \%$. Our study including 32 patients is the largest study of performing GMT on IBD patients in the literature so far.

Compared to other studies on GMT, the current study group consisted entirely of patients with IBD, which is generally associated with lower fistula healing rates using different procedures [6, 9, 24-26]. Some patients with IBD show apparent late recurrences; however, some of these may be attributable to spontaneous development of new fistula due to $\mathrm{CD}$ activity, rather than a recurrence of a previous fistula.

No significant difference in terms of age was detected between the groups with remission and recurrence. Therefore, the authors would recommend the procedure for IBD patients of all ages. There was also no significant difference in healing rate between patients taking $C D$ specific 
medications and patients not taking any $\mathrm{CD}$ specific medications at time of GMT.

Fistula persistence after GMT was detected no later than at the first follow-up after GMT, and was treated accordingly. Late recurrences, however, appeared unequally distributed after a mean of 24 months after GMT (median 23 months, range 5-62 months). Almost half of the recurrences took place 5-7 months after GMT and the others appeared 1.5-5 years postoperatively. Another follow-up with clinical examination and anorectal sonography 6-9 months after GMT might be advantageous for earlier detection of a recurrence and initiation of treatment.

Adequate treatment of IBD seems to have a positive impact in preventing late recurrences. Due to the small number of patients in the present cohort, it was not possible to detect whether success after GMT correlated with the different types of $\mathrm{CD}$ medication.

The fact that all GMTs were performed by a single surgeon using a standardized procedure reduced the possibility of the outcome being influenced by varying skill levels of different surgeons.

The study has some limitations. First, only a small number of patients were included. Further studies with larger patient numbers are needed. There are, however, only a few similar studies on fistula treatment in IBD patients in the recent literature.

Due to its retrospective design, the current study lacks a uniform follow-up period. A defined interval between the procedure and examination of the patients could improve comparison between the different patients and success rates. The follow-up at 3 months postoperatively did not apply to all patients, mainly because some suffered a persistent fistula and were examined earlier than after 3 months. The next follow-up after the 3-month follow-up was also somewhat heterogeneous, since most patients received a further followup only due to complaints; a large proportion of the patients who achieved complete remission and stoma closure did not attend further examinations.

Another critical point of the study is the correlation between GMT and the fistula closure rate when additional procedures were needed. It is impossible to determine the exact extent of the contribution of GMT to the fistula closure rate when additional operations were performed after GMT. The authors are convinced that the gracilis muscle is the basis for the success of additional fistula operations. Larger trials directly comparing GMT to other surgical procedures with a long follow-up period should be performed to better understand its benefits. This would contribute to determining the best way to treat recurrent fistulas in patients with IBD (Table 7).

\section{Conclusions}

Our results are promising and suggest that GMT is a safe and very effective option for the treatment of recurrent fistulas in IBD patients. It should be noted that for complete fistula closure, follow-up procedures may be necessary. The option of dynamization of the muscle creates the possibility of improving fecal continence and, thus, quality of life. The authors suggest that in cases of recurrence after initially addressing a fistula with conventional methods, and after repeated unsuccessful procedures, GMT should be considered.

Table 7 Comparison of pre-existing studies

\begin{tabular}{|c|c|c|c|c|c|}
\hline Author & Year & $\begin{array}{l}\text { Number of } \\
\text { patients }\end{array}$ & Fistula type & Follow-up period (months) & Success rate \\
\hline Zmora et al. [8] & 2003 & 11 & RUF & 4-40 (median 18, 2) & $100 \%$ \\
\hline Fürst et al. [10] & 2008 & 12 & RVF and anovaginal & Mean 40 & $91.6 \%$ \\
\hline Wexner et al. [9] & 2008 & 17 & $\begin{array}{l}15 \times \mathrm{RVF} \\
2 \times \text { pouch-vaginal }\end{array}$ & & $\begin{array}{l}\text { 33\% (Crohn's) } \\
\text { and 75\% (non- } \\
\text { Crohn's) }\end{array}$ \\
\hline Wexner et al. [9] & 2008 & 36 & RUF & & $97 \%$ \\
\hline Lefevre et al. [5] & 2009 & 8 & RVF & 4-55 (median 28) & $88 \%$ \\
\hline Ulrich et al. [6] & 2009 & 35 & $\begin{array}{l}9 \times \mathrm{RVF} \\
26 \times \mathrm{RUF}\end{array}$ & Mean $28 \pm 15$ & $94 \%$ \\
\hline Maeda et al. [7] & 2011 & 14 & Complex fistula & 1-88 (median 10) & $64 \%$ \\
\hline Maeda et al. [7] & 2011 & 4 & Persistent nonhealing perineal sinus & 1-88 (median 10) & $50 \%$ \\
\hline Chen et al. [4] & 2013 & 19 & RUF and RVF & 6-35 (median 18) & $94.7 \%$ \\
\hline Current study & 2018 & 32 & RVF, RUF, pouch-vaginal, and anovaginal & $1-144$ (mean 47) & $71 \%$ \\
\hline
\end{tabular}

$R U F$ rectourethral fistula, $R V F$ rectovaginal fistula 
Acknowledgements S. Korsun contributed to study design, collected and analyzed the data, and wrote the manuscript. G. Liebig-Hoerl assisted in data collection. A. Fuerst supervised data collection, data analysis, the study, and corrected the paper.

Funding The authors did not receive any funding for this study.

\section{Compliance with ethical standards}

Conflict of interest The authors declare that they have no conflicts of interest in connection with this study.

Ethical approval This article does not contain any studies with human participants or animals performed by any of the authors.

Informed consent For this type of study, formal consent is not required.

Open Access This article is distributed under the terms of the Creative Commons Attribution 4.0 International License (http://creativecommons.org/licenses/by/4.0/), which permits use, duplication, adaptation, distribution and reproduction in any medium or format, as long as you give appropriate credit to the original author(s) and the source, provide a link to the Creative Commons license and indicate if changes were made.

\section{References}

1. Scharl M, Huber N, Lang S et al (2015) Hallmarks of epithelial to mesenchymal transition are detectable in Crohn's disease associated intestinal fibrosis. Clin Transl Med 4:1

2. Bataille F, Rohrmeier C, Bates R et al (2008) Evidence for a role of epithelial mesenchymal transition during pathogenesis of fistulae in Crohn's disease. Inflamm Bowel Dis 14(11):1514-1527

3. Siegmund B, Feakins RM, Barmias G et al (2015) Results of the fifth scientific workshop of the ECCO (II): pathophysiology of perianal fistulizing disease. J Crohn's Colitis 10(4):377-386

4. Chen XB, Liao DX, Luo CH et al (2013) [Prospective study of gracilis muscle repair of complex rectovaginal fistula and rectourethral fistula]. Zhonghua Wei Chang Wai Ke Za Zhi 16(1):52-55

5. Lefevre JH, Bretagnol F, Maggiori L et al (2009) Operative results and quality of life after gracilis muscle transposition for recurrent rectovaginal fistula. Dis Colon Rectum 52(7):1290-1295

6. Ulrich D, Roos J, Jakse G, Pallua N (2009) Gracilis muscle interposition for the treatment of recto-urethral and rectovaginal fistulas: a retrospective analysis of 35 cases. J Plast Reconstr Aesthet Surg 62(3):352-356

7. Maeda Y, Heyckendorff-Diebold T, Tei TM, Lundby L, Buntzen $S$ (2011) Gracilis muscle transposition for complex fistula and persistent nonhealing sinus in perianal Crohn's disease. Inflamm Bowel Dis 17(2):583-589

8. Zmora O, Potenti FM, Wexner SD et al (2003) Gracilis muscle transposition for iatrogenic rectourethral fistula. Ann Surg 237(4):483-487

9. Wexner SD, Ruiz DE, Genua J et al (2008) Gracilis muscle interposition for the treatment of rectourethral, rectovaginal, and pouch-vaginal fistulas: results in 53 patients. Ann Surg 248(1):39-43

10. Fuerst A, Schmidbauer C, Justyna S-B et al (2008) Gracilis transposition for repair of recurrent anovaginal and rectovaginal fistulas in Crohn's disease. Int J Colorectal Dis 23(4):349-353

11. Fuerst A (2017) Gracilis transposition for repair of recurrent rectovaginal fistula. Coloproctology 39(2):84

12. Borda Mederos LA, Chiroque Benites LI, Pinto Elera JO, Manzaneda Pineda AJ (2011) [Experience with a biological plug for biological in complex anal fistula]. Rev Gastroenterol Peru 31(4):345-350

13. Cintron JR, Abcarian H, Chaudhry V et al (2013) Treatment of fistula-in-ano using a porcine small intestinal submucosa anal fistula plug. Tech Coloproctol 17(2):187-191

14. Kleif J, Hagen K, Wille-Jorgensen P (2011) Acceptable results using plug for the treatment of complex anal fistulas. Dan Med Bull 58(3):A4254

15. Schwandner T, Roblick MH, Kierer W et al (2009) Surgical treatment of complex anal fistulas with the anal fistula plug: a prospective, multicenter study. Dis Colon Rectum 52(9):1578-1583

16. Schwandner O, Fuerst A, Kunstreich K, Scherer R (2009) Innovative technique for the closure of rectovaginal fistula using Surgisis mesh. Tech Coloproctol 13(2):135-140

17. Champagne BJ, O'Connor LM, Ferguson M et al (2006) Efficacy of anal fistula plug in closure of cryptoglandular fistulas: longterm follow-up. Dis Colon Rectum 49(12):1817-1821

18. Chan S, McCullough J, Schizas A et al (2012) Initial experience of treating anal fistula with the Surgisis anal fistula plug. Tech Coloproctol 16(3):201-206

19. El-Gazzaz G, Zutshi M, Hull T (2010) A retrospective review of chronic anal fistulae treated by anal fistulae plug. Colorectal Dis 12(5):442-447

20. Lawes DA, Efron JE, Abbas M, Heppell J, Young-Fadok TM (2008) Early experience with the bioabsorbable anal fistula plug. World J Surg 32(6):1157-1159

21. Panes J, Garcia-Olmo D, Van AG et al (2016) Expanded allogeneic adipose-derived mesenchymal stem cells (Cx601) for complex perianal fistulas in Crohn's disease: a phase 3 randomised, double-blind controlled trial. Lancet 388(10051):1281-1290

22. Panes J, Rimola J (2017) Perianal fistulizing Crohn's disease: pathogenesis, diagnosis and therapy. Nat Rev Gastroenterol Hepatol 14(11):652-664

23. Panes J, Ordas I, Ricart E (2010) Stem cell treatment for Crohn's disease. Expert Rev Clin Immunol 6(4):597-605

24. Athanasiadis S, Oladeinde I, Kuprian A, Keller B (1995) Endorectal advancement flap-plasty vs. transperineal closure in surgical treatment of rectovaginal fistuls. A prospective long-term study of 88 patients. Chirurg 66(5):493-502

25. MacRae HM, McLeod RS, Cohen Z, Stern H, Reznick R (1995) Treatment of rectovaginal fistulas that has failed previous repair attempts. Dis Colon Rectum 38(9):921-925

26. Jones IT, Fazio VW, Jagelman DG (1987) The use of transanal rectal advancement flaps in the management of fistulas involving the anorectum. Dis Colon Rectum 30(12):919-923

Publisher's Note Springer Nature remains neutral with regard to jurisdictional claims in published maps and institutional affiliations. 